\title{
Medel för nationsbyggande
}

\section{Âsa Olovsson}

Den stora plåtburken med knäckebröd i är dekorerad med snirkliga bokstäver. Där står "Swedish souvenir". På burken finns motivet av en leende same. Han är klädd i sin färgrika kolt och har en lappmössa med röd, stor tofs på. När jag tittar på bilden påminns jag om den samedräkt jag fick som barn. Denna minnessak ligger numera i kistan med utklädningskläder och används av mina barn. Souvenirerna i mitt hem visar hur ett kolonialt arv finns i vår vardag och hur det förs över till nästa generation.

Ett helt annat arv kommer från den traditionellt nationalistiska historieskrivningen. Där finns en mängd exempel på heroiska förebilder som kungar, hjältar och upptäckare, vilka hyllats av nationen. De har skrivits in som starka aktörer bakom nationens bildande och framåtskridande och blivit redskap i kampen om historien. Upphöjda mäns nationella och internationella insatser har gjorts för landets bästa. Men det finns kanske en sanning däremellan. Där det koloniala arvet på ett måhända oväntat sätt har använts för att stärka den nationella självbilden.

Från ett postkolonialt perspektiv definierar man sin egen identitet genom att ta fasta på skillnaden gentemot det som är annorlunda. Till följd av den europeiska expansionen av världen har begreppet den Andre tillämpats som markering för avståndet mellan vi och dem. Denna utveckling har också medfört att den Andre är ett vidgat begrepp. Det kan alltså röra samer såväl som inuiter och indianer, men det kan lika väl handla om det afrikanska zulufolket. Med avstamp i denna tanketradition, kan en koloniserande dominant kultur använda den Andre som referens för att bygga upp den egna nationella självbilden. Ur det perspektivet finns det skäl att vid sidan av modiga män se den koloniserade Andre som medel för nationsbyggande även i Norden.

Nämnda souvenirer är exempel på hur den Andre använts som symboler i ett ekonomiskt syfte för att sälja Sverige. Andra ting är etiketter på tändsticksaskar. Etiketter med etnografiska motiv har varit viktiga i marknadsföringssyfte. Med intentionen att göra Sveriges tändsticksindustri känd under den industriella epoken har samemotiv använts. Men även andra koloniserade har utgjort motiv. Ett exempel är 'Tre lättklädda afrikanska kvinnor" (Loewe 1997: 74). Den Andre har varit ett medel för den svenska tändsticksindustrin att nå framgångar på exportmarknaden. Den stora produktionen belyser hur Sverige finansiellt har kunnat visa sig starkt i förhållande till andra nationer genom att utnyttja varumärken där den Andre varit ett centralt inslag. Symbolerna har förstärkt den nationella identifikationen, men har också upprätthållit avståndet till den Andre.

Den Andre har även använts i en kontext som rör reseskildringar, vilket medfört att distansen mellan vi och dem har befästs. Exempel från 1800-talet som frammanat sådana berättelser är Vegaexpeditionen, med Adolf Erik Nordenskiöld i spetsen, samt Knud Rasmussens polarexpeditioner. Visserligen blev polarforskarna nationalsymboler i sig, men deras skildringar av den arktiske Andre användes även i syfte att nå berömmelse. Det finns exempel som pekar på att de erövrade nationerna "utvecklade sin identitet som överlägsna civilisationer med en mission [ ] att civilisera" (Wallin Weihe 1999: 167 [min övers.]). Polarexpeditionerna var en investering för nationerna, när det gällde att visa sig självständiga. Av det skälet kan äventyrsskildringarna med ett exotiskt innehåll ses som medel för uppbyggnad av en civiliserad nationell självbild, här för Sveriges och Danmarks del. 
Fördjupad kunskap om den Andre har även skett med vetenskaplig intention. Det skedde mot bakgrund av tidiga upptäckare och var ett led i den ökade europeiska expansionen. Kultur omvandlades och klassificerades. Ett exempel visar hur finländska vetenskapsmän genomförde antropologiska studier i Sydamerika och Nya Guinea i början på 1900-talet. På så vis har de kunnat använda sin nyvunna kunskap om den Andre "för att etablera sig själva som akademiker och stärka sin vetenskapliga auktoritet” (Hollsten 2007: 90 [min övers.]). Exemplet visar att forskning kan betraktas som statusmarkör, vilken bidragit med att förhöja den nationella självbilden.

Denna slags forskning har i sin tur påverkat beskrivningen av den koloniserade Andre i den allmänna historieskrivningen. Även om omfattningen är ringa finns det i den svenska grundskolans böcker inslag, där den Andre pekas ut som något främmande och farligt. I en bok från 1960-talet omnämns zulufolket. Om dem sägs: "Zulukaffrerna i Sydafrika var farliga fiender till de vita [ ] Här rusar de fram mot en engelsk trupp, som de nästan tillintetgjorde.” (Olovsson 1998: 16). Stoffet i läroböckerna har signalerat värderingar och ideal som markerat avståndet mellan vi och dem. Dessa kan anslutas till den nationella självbilden och uppfattningen att vi till skillnad från dem är civiliserade.

I en helt annan kontext kan den Andre också betraktas som redskap för svenskarna att kunna visa sig starka jämfört med andra folk. I det här fallet handlar det utnyttjandet av båtsmän från den östra rikshalvan i form av arbetskraft, men även ifråga om att försvenska den tidigare danska provinsen Blekinge (Villstrand 1987). Huvudskälet var lättillgänglig manskap, eftersom Karlskrona i slutet av 1600-talet hade grundats som flottbas. Men de förhållanden som båtsmännen fick uppleva var miserabla. På sin nya hemort väckte de anstöt och upplevdes som främlingar. Förvisso har det diskuterats om Finland kan betraktas som koloni till det svenska riket. Men det finns forskning som framhåller att Finland varit "en underordnad [och] till och med förtryckt del av det svenska riket" (Engman 2008: 133). Det perspektivet uppmuntrar till att betrakta de finska båtsmännen som medel i konstruktionen av den svenska nationalstaten.

Då den koloniserade Andre har skymtat på tändsticksetiketter, i reseskildringar, i vetenskapliga studier, i läroböcker samt också varit redskap i införlivningen av territorium, finns flera skäl att se den koloniserade Andre som medel för nationsbyggande i Norden. Erövrande nationer har inte kunnat framstå som starka och framgångsrika enbart med kungar, hjältar och erövrare som medel. För att kunna uttrycka en nationell identifikation tillsammans med civilisation, har det krävts att nationen kunnat mäta sig med något. De här exemplen visar att den har gjort det på bekostnad av den Andre. Utan den Andre fanns ingen möjlighet att uttrycka: Vi var där, vi upptäckte, vi är starka och modiga och vi har kunskap. Det var ett sätt för redan väl rustade nationer att vinna kampen om historien.

\section{Referenser}

Engman, Max, 2008, "Tack för bildningens och lagstiftningens gåfva" i Ord \& bild, Norden \& kolonialismen $\mathrm{nr} 2$.

Granqvist, Karin, 2007, 'Between the Arctic 'Other and subject'" i Encountering Foreign Worlds. Experiences at Home and Abroad. Proceedings from the 26Th Nordic Congress of Historians. Reykjavik 8-12 Augusti 2007, red. Guðmundur Jónsson.

Hollsten, Laura, 2007, "Among Indian tribes and Kiwai Papuans" i Encountering Foreign Worlds. Experiences at Home and Abroad. Proceedings from the 26Th Nordic Congress of Historians. Reykjavik 8-12 Augusti 2007, red. Guðmundur Jónsson. 
Loewe, Walter, 1997, De tände en eld. Svensk tändsticksindustri 1836-1996. Stockholm.

Olovsson, Åsa, år? ”Budskap, uttryck och förändring i historieläroböcker från 1960 till 1980-tal", D-uppsats, Högskolan på Gotland.

Said, Edward W., 2004, Orientalism. Stockholm.

Villstrand, Nils Erik, 1987, "Från det avlägsna Finland till orter nära flottan. De finska båtsmanskompaniernas förflyttning på 1680-talet", i Kustbygd och centralmakt 1560-1721. Helsingfors.

Wallin Weihe, Hans-Jørgen, 1999, Social work and Missionary Work as part of the power game. Meddelanden från Socialhögskolan 1999:3. Lund. 